\title{
PRINCIPAIS DOENÇAS DE ANONÁCEAS NO BRASIL: DESCRIÇÃO E CONTROLE ${ }^{1}$
}

\author{
NILTON TADEU VILELA JUNQUEIRA² \& KEIZE PEREIRA JUNQUEIRA ${ }^{3}$
}

RESUMO- Várias doenças podem afetar folhas, caules, flores e frutos de gravioleira, pinheira e atemoia em diferentes estádios de seus desenvolvimentos. Geralmente, as doenças mais importantes são causadas por fungos durante o florescimento e a frutificação. Também podem ocorrer murchas ou podridões de raízes, causadas por nematoides e patógenos do solo. A antracnose (Colletotrichum gloeosporioides), murcha ou podridões de raízes (Rhizoctonia solani, Cylindrocladium clavatum, Phytophthora sp., Pythium sp., Phytophthora nicotianae var. parasitica, cancros (Albonectria rigidiuscula) e podridão de frutos (Botryodiplodia theobromae, sin. Lasiodiplodia theobromae) são as mais importantes. Por outro lado, a podridão-parda-do-fruto (Rhizopus stolonifer) provoca perdas expressivas na produção de graviola. A seguir, são descritas as principais doenças que afetam estas espécies de anonáceas, seus agentes causais e as medidas de controle.

Termos para indexação: Fitossanidade, graviola, pinha, atemoia, cherimoia.

\section{MAJOR DISEASES OF ANNONACEAE IN BRAZIL: DESCRIPTION AND CONTROL}

\begin{abstract}
Several diseases can infect leaves, stem, roots, flowers and fruits of soursop, custard apple and atemoya on different stage of their development. Generally, the most important diseases are caused by fungi during the flowering and fruit set. Rot root diseases and wilts caused by nematodes and soil pathogens also can induce expressive losses. Anthracnose (Colletotrichum gloeosporioides), wilt or rot root (Rhizoctonia solani, Cylindrocladium clavatum, Phytophthora sp., Pythium sp., Phytophthora nicotianae var. parasitica), canker disease (Albonectria rigidiuscula) and rot fruit (Botryodiplodia theobromae, sin. Lasiodiplodia theobromae) are the most important. Moreover, the fruit brown rot (Rhizopus stolonifer) cause expressive losses in soursop production. Following it will be described the major diseases affecting these Annonaceae species, their main causal agents and control measures.
\end{abstract}

Index terms: Phitossanity, soursop, sweetsop, atemoya, cherimoya.

\section{INTRODUÇÃO}

Várias doenças podem afetar as folhas, ramos, raízes, flores e frutos da gravioleira, ateira, atemoleira e cherimoleira em diferentes etapas de seu desenvolvimento. De maneira geral, as de maior importância no Brasil são causadas por fungos, durante o florescimento e a frutificação. Os fungos são responsáveis por até $63 \%$ de perdas de frutos de gravioleira em campo (JUNQUEIRA et al., 1996; JUNQUEIRA et al., 2003) e de 90\% na pós-colheita (NIETO-ANGEL et al., 1998), ao passo que nematoides da espécie Pratylenchus coffea, principal agente causal da morte súbita da gravioleira, vêm provocando danos consideráveis na região Nordeste (FREIRE et al., 2011).
Em fruteira-do-conde ou ateira, assim como em atemoleira e cherimoleira, a antracnose (Colletotrichum gloeosporioides), seguida pela cancrose e podridão-de-raízes, causa prejuízos expressivos em todos os pomares do mundo (JUNQUEIRA et al., 2003; AGUSTÍN; ALVITER, 1996). Não são relatados grandes prejuízos decorrentes do ataque por bactérias ou vírus.

A seguir, são relatadas as principais doenças que acometem a gravioleira, ateira, atemoleira e cherimoleira, seus respectivos agentes causais e principais medidas de controle. Junqueira et al. (2003) descrevem e ilustram várias doenças que podem ocorrer nestas quatro anonáceas, desde a sementeira até em pós-colheita. Algumas doenças, como a antracnose, podridões de frutos e doenças

\footnotetext{
${ }^{1}$ Palestra Anonáceas - V Congresso Internacional \& Encontro Brasileiro sobre Annonaceae: do gene à exportação (19 a 23 de Agosto de 2013). Botucatu-SP.

${ }^{2}$ Eng. Agrônomo, Dsc. Fitopatologia, Pesquisador da Embrapa Cerrados, BR 020 Km 18, Planaltina, DF - Brasil - CEP $73310-970$, Caixa Postal: 08223.E -mail: nilton.junqueira@embrapa.br

${ }^{3}$ Eng. Agrônoma, Dsc. Fitopatologia, Pesquisadora da Embrapa Produtos e Mercado, Prédio da Embrapa Sede - Parque Estação Biológica - PqEB s/nº., Brasília, DF - Brasil - CEP 70770-901. E -mail: keize.junqueira@embrapa.br
} 
de raízes são comuns nessas quatro anonáceas e, na maioria das vezes, são causadas por patógenos do mesmo gênero ou espécie.

\section{Antracnose \\ (Coletotrichum gloeosporioides Penz.)}

A antracnose ou "podridão-negra-dos-frutos" é considerada a moléstia mais importante dessas anonáceas, chegando a provocar de $53 \%$ a $70 \%$ de perdas de frutos quando ocorrem chuvas prolongadas durante a floração e formação de frutos. Ocorre em todos os países que cultivam anonáceas. Incide preferencialmente nos tecidos jovens de folhas, ramos, flores e frutos.

Em pinheira ou fruteira-do-conde, os sintomas são caracterizados, nas folhas, por manchas de coloração pardo-escura ou preta, com o centro mais claro, de contorno irregular, distribuídas por todo o limbo foliar. As folhas ficam deformadas e, em ataques mais severos, ocorre desfolhamento. As lesões, inicialmente, são pequenas, mas, com o passar do tempo, podem atingir mais de um centímetro de diâmetro. Nos ramos, são encontradas lesões alongadas, deprimidas, que podem provocar a morte das ponteiras. Nas flores, aparecem manchas circulares, de coloração castanho-escura, que impedem o vingamento e provocam quedas expressivas.

Os frutos podem ser atacados em qualquer estádio de desenvolvimento. Nos frutos jovens, ocorre escurecimento de toda a sua superfície, queda e mumificação. Em frutos desenvolvidos, que estão iniciando o seu amadurecimento, ou nos maduros, causa uma podridão escura de rápida evolução, inutilizando o fruto para o consumo ou para sua comercialização (JUNQUEIRA et al., 2003; RIBEIRO, 1992; FREIRE;CARDOSO, 1997; MORALES; MANICA, 1994).

Em atemoleira e cherimoleira, segundo Tokunaga (2000), Bonaventure (1999) e Takanaki (2008), a antracnose é considerada a doença mais importante da parte aérea. Na brotação nova, compromete o desenvolvimento da planta; nas fases de florescimento e frutificação, ataca o pedúnculo ocasionando a queda de flores e frutos. Agustin e Alviter (1996) relatam que a incidência dessa doença em frutos de cherimólia, em algumas regiões do México, pode variar de 50 a $70 \%$. Sua incidência nas brotações novas compromete o desenvolvimento da planta. Nas fases de florescimento e frutificação, ataca o pedúnculo ocasionando a queda de flores e frutos.

Nos frutos, os sintomas iniciais são caracterizados por pequenas manchas escuras na casca. Com o tempo, as lesões aumentam de tamanho, podendo coalescer e atingir toda a superfície do fruto, às vezes provocando rachaduras profundas na casca. Os frutos mais novos ou em fase de desenvolvimento, quando não caem, tornam-se escuros e mumificados (KAVATI, 1992; JUNQUEIRA et al., 2003). Sob condições de alta umidade relativa ou em períodos com chuvas prolongadas, sobre as lesões escuras ou em frutos mumificados, surge uma pigmentação de coloração rosa-amarelada que são as frutificações (acérvulos) do patógeno, prontos para uma nova infecção. Os frutos com diâmetro igual ou superior a 6 (seis) centímetros tornam-se mais resistentes à infecção, mas em períodos com chuvas prolongadas e temperaturas em torno de $22^{\circ} \mathrm{C}$, pode ocorrer infecção que provoca manchas na casca. Essas manchas tendem a concentrar-se nas proximidades do pedúnculo devido ao maior acúmulo de água ou umidade nessa parte do fruto.

Nos ramos novos, podem ocorrer lesões escuras, alongadas ou circulares, que prejudicam o crescimento do ramo ou da planta nova em campo ou em viveiro. Nas folhas, podem ocorrer lesões escuras com formato irregular que provocam deformações e queda. As flores tornam-se escuras e caem. Geralmente, em períodos de alta umidade, ocorre intensa queda de flores.

Em gravioleira, esta doença ataca folhas, brotações novas, flores e frutos de qualquer idade, causando a morte de ramos, enxertos, queda de frutos e flores. Segundo estudos relatados por Junqueira et al. (2003), a antracnose é a doença que provoca maiores prejuízos na gravioleira em sua fase de frutificação. Nieto-Angel et al. (1998) relataram que a antracnose já chegou a ser responsável por $90 \%$ de perda de frutos de gravioleira na Bahia.

Os sintomas caracterizam-se pela morte das brotações novas ou ramos ponteiros e pela formação de lesões necróticas escuras e irregulares nas folhas e nas brotações novas. Quando as condições climáticas são muito favoráveis, o fungo pode atacar os botões florais, frutos de qualquer idade e até causar a morte de ramos ponteiros (die back). Quando ataca frutos novos, estes se tornam escuros, mumificados e permanecem na planta por algum tempo. Em frutos desenvolvidos, sobre a casca, podem ocorrer numerosas lesões geralmente circulares, escuras, profundas, que podem coalescer e provocar rachaduras. Sobre estas lesões, pode ser visualizada uma massa rosa que são as frutificações do fungo. Quando a infecção ocorre em frutos mais jovens, as lesões individuais podem aumentar rapidamente de tamanho, tornando-se profundas e podendo atingir até $15 \mathrm{~cm}$ de diâmetro. Em mudas enxertadas, o patógeno pode atacar o 
ponto de ligação enxerto/porta- enxerto, reduzindo drasticamente a taxa de pegamento da enxertia ou provocando a morte dos enxertos.

Essa doença é causada pelo fungo Colletotrichum gloeosporioides Penz. que, na forma perfeita ou sexuada, corresponde ao fungo Glomerella cingulata (ston.) Spauld e Scherenk. Este fungo sobrevive de um período favorável para outro em ramos secos, lesões antigas, frutos e partes afetadas remanescentes no chão, sobre os quais esporula quando há calor e umidade. A disseminação é feita principalmente pelo vento e respingos de chuva. Alta umidade e temperaturas noturnas de 20 a $24^{\circ} \mathrm{C}$, adubações inadequadas ou ataque de pragas favorecem a doença.

Como medidas de controle, em pinheira, atemoleira e cherimoleiras, recomendam-se eliminar galhos secos e frutos mumificados do pomar; fazer podas periódicas para tornar as copas mais ventiladas e fazer pulverizações preventivas com fungicidas à base de oxicloreto de cobre $(2 \mathrm{~g} / \mathrm{L})$ intercalado com mancozeb $(2 \mathrm{~g} / \mathrm{L})$, em intervalos semanais, durante o período chuvoso e, se necessário, a cada 20 ou 30 dias durante o período da seca. Fungicidas à base de difenoconazole, tebuconazole e estrobilurinas são eficazes, no entanto não estão registrados junto ao Ministério da Agricultura para uso em anonáceas. É importante ressaltar que a primeira pulverização deve ser feita a aproximadamente 15 dias do início da florada. Os fungicidas à base de cobre não devem ser aplicados durante a florada, pois podem provocar queda intensa de flores e frutinhos, principalmente se aplicados nas horas mais quentes do dia. Outros fungicidas, como tiabendazol, clorothalonil e tiofanato metílico, também são eficazes, mas não estão registrados para anonáceas.

Em gravioleira, como medidas de controle, recomendam-se: efetuar os tratos culturais; o controle de pragas e adubações adequadas; eliminar ramos e frutos doentes ou secos do pomar; efetuar poda de limpeza, visando a eliminar os ramos secos da planta. Caso a doença esteja atacando a folhagem ou os ramos das plantas, ela pode ser controlada por aplicações de oxicloreto de cobre a $0,15 \%$, intercalado com tebuconazole, difenoconazole ou estrobilurinas, a intervalos de 7 a 10 dias, durante o período chuvoso, e de 15 a 20 dias durante o período seco. Aplicações com mancozeb a $0,24 \%$ e tiofanato metílico a $0,14 \%$ também controlam bem a doença. Fungicidas à base de difenoconazol, tebuconazole e estrobilurina também são eficazes no controle da antracnose. Entretanto, esses produtos não estão registrados para uso em anonáceas.

No caso de a maior incidência da doença ocorrer em flores e frutos, recomenda-se que as aplicações sejam realizadas diretamente sobre os frutos e flores. Nesse caso, o uso de pulverizadores costais com bicos acoplados em hastes longas é ideal para essa operação. Em locais de incidência da broca-do-fruto e/ou da semente, recomenda-se o controle dessas pragas antes da aplicação de fungicidas, pois elas provocam ferimentos nos frutos, que servem de portas de entrada para fungos.

\section{Podridão-de-raízes}

(Rhizoctonia solani, Pythium sp., Phytophthora spp., Cylindrocladium clavatum e nematoides da espécie Pratylenchus coffeae)

Também conhecida como podridão-do-colo, a podridão-de-raízes é uma doença de grande expressão econômica no Estado de São Paulo e Cerrados do Distrito Federal, Minas Gerais e Goiás. Essa doença afeta o colo e as raízes das plantas de anonáceas cultivadas que acabam morrendo. No Nordeste, Freire et al. (2011) constataram o nematoide Pratylenchus coffeae associado a necroses, escurecimento do tecido de raízes e morte de pinheira e gravioleira.

Os sintomas dessa doença, inicialmente, são caracterizados pela redução do tamanho e perda da coloração original da folhagem, que adquire uma tonalidade verde-pálida. As plantas param de crescer e emitem poucas brotações. Os frutos apresentam tamanhos reduzidos e caem antes mesmo de chegar ao ponto de colheita. Em seguida, ocorre a murcha das brotações mais novas e um amarelecimento generalizado das folhas mais velhas, que secam e caem posteriormente.

Em estado inicial da doença, na região do colo ou coleto da planta, podem ser observadas rachaduras ou manchas escuras que atingem a região do câmbio. Com o tempo, as lesões aumentam de tamanho e progridem em direção às raízes, tornando-as escuras e podres. A planta seca completamente. Plantas de qualquer idade podem ser atacadas. Em viveiros, os sintomas iniciais são caracterizados pelo aparecimento de lesões (manchas escuras) ou de um fendilhamento da casca na região do coleto ou logo acima. As mudas param de crescer, as folhas novas ficam pequenas e retorcidas. Abaixo do coleto, observa-se podridão da casca ou escurecimento do tecido, podendo essa podridão escura estender- se para todo o sistema radicular. Como consequência, a planta não brota e tomba com facilidade, podendo amarelecer e morrer depois de certo tempo.

Os agentes causais são os fungos Rhizoctonia solani, Cylindrocladium clavatum, Phytophthora sp., Pythium sp. e Phytophthora nicotianae var. parasi- 
tica. Este último também pode causar mumificação de frutos da parte baixa da copa. A incidência da doença em mudas é favorecida pelo excesso de água durante a irrigação, pelo excesso de sombreamento do viveiro, pelos recipientes ou saco de polietileno com poucas perfurações ou com má drenagem e/ou contendo substratos com muita matéria orgânica ou por solo muito argiloso. Em campo, essa doença é favorecida pelos plantios em solos mal drenados, por excesso de esterco nas covas, por períodos chuvosos prolongados, aliados a temperaturas inferiores a $22^{\circ} \mathrm{C}$ e, em muitos casos, por mudas infectadas. No Distrito Federal, a maior incidência tem sido observada nos meses de fevereiro e março, época em que os períodos prolongados de chuva ocorrem acompanhados de temperaturas mais baixas.

Para o controle da doença, recomenda-se: eliminar o excesso de água e o sombreamento no viveiro; sempre que possível, usar substratos mais leves nos recipientes, reduzindo a quantidade de esterco, e usar, de preferência, solos menos argilosos na composição desse substrato; evitar manter os sacos de polietileno no chão, pois os respingos de água que tocam ao solo são os principais disseminadores desses fungos; usar, de preferência, substratos esterilizados ou comerciais; eliminar mudas contaminadas; evitar o plantio em solos rasos ou mal drenados ou muito argilosos. Se isso não for possível, recomenda-se fazer o plantio em camalhões e nunca deixar que água de chuva ou de irrigação acumule no pé da planta; durante a irrigação, evitar o excesso de água, principalmente nas regiões onde o período seco coincide com o período mais frio do ano. Em caso de irrigação por gotejamento, manter os emissores a, no mínimo, $70 \mathrm{~cm}$ do coleto das plantas. Recomenda-se o uso do porta-enxerto de condessa (Annona reticulata) para pinheira e atemoleira, visto que apresenta maior tolerância à doença, embora os resultados não sejam totalmente satisfatórios em ateira devido a alguns problemas de compatibilidade com a atemoleira. O biribá amazônico (Rollinea mucosa) também vem mostrando potencial como porta-enxerto para gravioleira no Distrito Federal, mas esta ainda não foi testada com copa de atemoleira e de outras anonáceas (JUNQUEIRA et al., 2003).

- Podridão seca do fruto e de ramos (Botryodiplodia theobromae, sin. Lasiodiplodia theobromae)

Esta doença pode afetar flores, botões florais, frutos, ramos e galhos de gravioleira, pinheira, atemoleira e cherimoleira de qualquer idade. Estresses hídricos, adubações desequilibradas e deficiência nutricional acentuada, fitoxidez por defensivos, alta pressão nos pulverizadores e ataques de pragas tornam as plantas vulneráveis ao ataque do fungo que necessita de algum tipo de ferimento para penetrar no interior dos tecidos. Uma vez penetrado no interior do tecido, o fungo progride rapidamente, provocando manchas pretas em frutos desenvolvidos e causando seca, queda de flores e de frutos jovens.

Nas flores e frutos novos, a doença provoca seca, morte e queda. Nos frutos desenvolvidos, o patógeno pode penetrar por aberturas naturais entre os frutilhos, pelo pedúnculo ou por ferimentos causados pelas pragas ou por outros tipos de ferimentos. Ao atingir a polpa do fruto, o fungo desenvolve-se rapidamente, causando o escurecimento de toda a superfície do fruto. Nestas condições, o fruto torna-se imprestável para o consumo, pois a polpa torna-se dura, escura e com sabor desagradável. O fruto atacado pode permanecer na planta por algum tempo ou cair no momento em que o fungo atingir o pedúnculo. Quando os frutos atacados permanecem no solo, desenvolve em suas cascas um micélio (mofo) preto ou cinza-escuro.

Na fase de pós-colheita, a doença caracteriza-se pelo aparecimento de lesões escuras na casca do fruto e escurecimento da polpa, tornando-a com sabor desagradável. Em plantas adultas, a doença, conhecida como podridão-seca, inicia-se nos ramos superiores, progredindo no sentido do ápice para a base até atingir o tronco e o coleto da planta. Nas partes atacadas, observa-se uma necrose escura na casca de ramos e caules de plantas jovens. Em plantas adultas e lenhosas, a necrose (escurecimento) pode ocorrer entre a casca e o câmbio. Em seguida, os ramos ou plantas atacadas secam e morrem. Em mudas, a doença inicia-se causando um escurecimento no ponto de ligação do enxerto com o porta-enxerto. Em seguida, a doença progride no sentido ascendente e/ ou descendente entre o câmbio e a casca, causando o escurecimento da casca.

O agente causal da podridão-da-casca é o fungo Botryodiplodia theobromae Pat., sin. Lasiodiplodia theobromae. É um fungo oportunista ou secundário que, para causar doença, necessita de algum ferimento para penetrar no interior dos tecidos da planta. Por esta razão, qualquer tipo de estresse, seja nutricional, hídrico ou causado por pragas e doenças, seja por fitotoxidez de defensivos agrícolas, torna as plantas e/ou frutos altamente vulneráveis ao ataque desse fungo. O Botryodiplodia theobromae sobrevive como saprófita em ramos secos, frutos secos deixados no pomar e em outros restos de cultura. A disseminação desse patógeno pode ser feita pelo próprio homem, pelo vento, pela chuva e por insetos que penetram nas flores e frutos. 
Como medidas de controle, recomenda-se: evitar qualquer tipo de estresse à planta, causado por ataque de pragas, adubação inadequada ou déficit hídrico; escolher o método de enxertia adequado. Nas regiões de Cerrado, o método "garfagem no topo em fenda cheia" tem favorecido a incidência da doença. O método "garfagem à inglesa simples" tem oferecido melhores índices de pegamento e de sobrevivência da muda.Em casos de ocorrência da doença, se ainda não houve o anelamento de troncos, recomenda-se raspar superficialmente a lesão e pincelar uma pasta à base de fungicidas; fazer os tratos culturais e adubações adequadas; controlar adequadamente as brocas-do-tronco, fruto e semente; evitar ferir o tronco durante os tratos culturais; fazer podas de limpeza, eliminando os galhos secos, as plantas mortas e os frutos velhos, caídos ou remanescentes. Após a poda, pulverizar os cortes com fungicidas à base de cobre e calda bordaleza a $1 \%$; durante as pulverizações, controlar a pressão no pulverizador para não ferir os frutos.

Nos casos em que a planta já estiver doente, recomenda-se a limpeza das áreas doentes com uma faca ou facão bem afiados. Em seguida, as partes descobertas devem ser protegidas com pasta fungicida, a pasta bordaleza, repetindo-se o tratamento mensalmente até que nenhuma lesão seja visível e tecidos de cicatrização iniciem sua formação (FREIRE; CARDOSO, 1997).

\section{- Murcha de Phytophthora}

É uma doença disseminada nos Estados de São Paulo, Goiás, Minas Gerais e Distrito Federal. Não se tem ainda confirmação da enfermidade em regiões produtoras do Norte e Nordeste (JUNQUEIRA et al., 1996; GRAMACHO et al., 2001; JUNQUEIRA et al., 2003). No Cerrado, o índice de mortalidade de pinheiras adultas em pomares implantados, em solos mais argilosos e com problemas de drenagem, está em torno de 12\%. Em solos mais arenosos, esse índice reduz-se para $2 \%$ de mortalidade. A doença manifesta-se também em atemoleiras e gravioleiras.

Os sintomas iniciais da doença manifestam-se na forma de uma discreta descoloração das folhas, as quais assumem uma coloração verde-clara, perdem o brilho e, em seguida, tornam-se cloróticas. Uma murcha incipiente surge antes que as folhas comecem a secar. As folhas mortas permanecem presas à planta. Na parte subterrânea, as raízes exibem sintomas de necrose e escurecem. As lesões podem atingir o colo da planta, chegando acima da linha do solo. Plantas de qualquer idade podem ser afetadas.

Em São Paulo, a doença é causada por Phytophthora nicotinae var. parasitica, enquanto em
Goiás e no Distrito Federal o fungo Phytophthora sp. ainda não foi identificado ao nível de espécie. A incidência é favorecida pelos plantios em solos mal drenados, excesso de esterco nas covas e por períodos chuvosos prolongados, aliados a temperaturas inferiores a $22^{\circ} \mathrm{C}$. Nos plantios no Cerrado de Goiás e Minas Gerais, e no Distrito Federal, a maior incidência tem sido observada nos meses de fevereiro e março. Em solos com $\mathrm{pH}$ naturalmente mais elevado, entre 6,0 e 7,0, ou nos solos denominados de "calcários" ou naqueles ricos em matéria orgânica, os índices de incidência dessa doença são muito baixos quando comparados aos solos ácidos.

Quanto ao controle, a doença é de difícil manejo em virtude de ser detectada somente quando as necroses do sistema radicular e do colo já se instalaram, tornando ineficaz qualquer medida curativa. Preventivamente, deve-se evitar o plantio de anonáceas em áreas passíveis de inundação ou encharcamento. Do mesmo modo, o plantio não deve ser feito em covas com bacias ou depressões, o que faz com que haja acúmulo de água de chuva ou de irrigação. Em pomares irrigados por gotejamento, manter os emissores afastados, no mínimo, a $70 \mathrm{~cm}$ do tronco. Também se recomenda preparar adequadamente o solo, aplicando os corretivos necessários de forma a atender às exigências das anonáceas quanto ao $\mathrm{pH}$, matéria orgânica e nutrientes. No Estado de São Paulo, essa doença vem sendo minimizada com o uso de porta-enxertos de condessa (Annona reticulata), que têm-se comportado como tolerantes à murcha de Phytophthora (KAVATI, 1992). O beribazeiro amazônico (Rollinia mucosa) vem-se comportando como resistente a essa doença, à podridão-de-raízes e à broca-do-coleto da gravioleira no Distrito Federal (JUNQUEIRA et al., 2003). No entanto, os índices de pegamento da enxertia nessa espécie têm sido baixos.

- Cancrose (Albonectria rigidiuscula, sin. Calonectria rigidiuscula, Nectria rigidiuscula)

Cancros são doenças comuns em anonáceas cultivadas. Em pinheira, atemoleira e cherimoleira, são causados pelo fungo Albonectria rigidiuscula (anamorfo: Fusarium decemcellulare), ao passo que,em gravioleira, esses cancros estão associados à presença dos fungos Phomopsis e Botryodiplodia. As plantas jovens podem morrer e, nas adultas, acarreta rachaduras longitudinais e deformações nos galhos que, com o tempo, podem matar a planta ou torná-la inútil. É uma das doenças de grande expressão para a cultura da pinha nos Cerrados de Goiás, Minas Gerais e Distrito Federal. Acredita-se que algum tipo de estresse causado pela falta de água e altitude elevada esteja favorecendo sua incidência. 
Inicialmente, observam-se áreas de tecidos dilatados em ramos mais desenvolvidos e troncos. Essas dilatações podem ser observadas mais frequentemente nas axilas de ramos. Com o passar do tempo, surgem pequenas rachaduras sobre essas áreas dilatadas, que aumentam rapidamente de tamanho e expõem o lenho. Nos cancros em estado adiantado, observa-se que tanto a casca como o lenho encontram-se escurecidos, e a seiva não circula, causando a morte da planta.

A infecção inicial é feita por conídios ou esporos de seu anamorfo, o Fusarium decemcelulare, ou por ascósporos de Albonectria rigidiuscula. A penetração desse patógeno ocorre por aberturas naturais nas axilas de ramos, por ferimentos causados por pragas, por danos mecânicos causados por ventos, pelos tratos culturais ou por estresse hídrico, por excesso de adubos e/ou de defensivos e escaldaduras. Após a penetração do fungo, ocorre a morte dos tecidos e uma reação imediata da planta, fazendo com que ocorram rachaduras e levantamento da casca, formando o cancro. Em seguida, o Fusarium passa produzir sua fase sexuada ou perfeita (Albonectria). Esta caracteriza-se por ser uma forma de resistência que sobrevive por longo período, transformando-se numa fonte de inóculo para infectar novamente a planta num próximo período favorável à infecção.

Como medidas de controle, devem-se: manter as plantas adubadas e com tratos culturais adequados; evitar estresses hídricos e controlar adequadamente as pragas; podar as plantas para permitir melhor aeração e para diminuir a umidade na copa. Após a poda, pincelar os cortes com uma pasta cúprica ou pulverizar a planta com calda bordaleza a $3 \%$ ou oxicloreto de cobre a $1 \%$; evitar podar a planta durante o período chuvoso ou quando ela estiver molhada; fazer o controle adequado de ervas daninhas e evitar ferimentos em ramos ou no tronco, principalmente durante o período chuvoso. Em casos de ocorrência da doença, se ainda não houve o anelamento de troncos, recomenda-se raspar superficialmente a área lesada e pincelar uma pasta de fungicidas à base de cobre.Caso já tenha havido anelamento, recomenda-se podar as partes afetadas.

- Cancro Depressivo ou Cancrose da Gravioleira (Phomopsis sp.)

O cancro depressivo ou cancrose, também denominada de "casca-preta", foi constatado em plantios de gravioleira localizados nas regiões Centro-Oeste, Nordeste e Norte (JUNQUEIRA et al., 2003). Afeta plantas de todas as idades, mas é mais frequente e mais severa em plantas com até um ano de idade. Entre as doenças da gravioleira que atacam tronco, raízes, ramos ou folhas, a cancrose é a que causa maiores danos econômicos. Nos Cerrados, vem causando um índice de até $7 \%$ de mortalidade de plantas com até três anos de idade.

Em plantas adultas, os sintomas iniciais são caracterizados pelo aparecimento de um exsudato preto nas axilas, na intersecção de ramos ou galhos ou no próprio tronco, às vezes formando grandes manchas visíveis a longas distâncias. Geralmente, no local dos exsudatos, podem ser observados rachaduras e um escurecimento do tecido sob a casca. É importante ressaltar que galhos ou ramos atacados pela broca-do-tronco também liberam exsudatos pretos. No entanto, sob esses exsudatos, existem orifícios redondos por onde a larva libera excrementos, e raramente estes sinais ocorrem em axilas ou nas intersecções de galhos. Em plantas jovens, normalmente, ataca ramos e o tronco das plantas, causando uma depressão na casca, que pode ser facilmente visualizada, às vezes com rachaduras. Sob a casca deprimida, podem ser observadas lesões escuras que circundam o tronco, apodrecendo a casca e o câmbio. Quando o ambiente favorece o patógeno, a doença progride tanto no sentido do colo para os galhos como dos galhos para o colo, causando total escurecimento dos tecidos sob a casca. Desta forma, o fluxo de seiva é totalmente bloqueado, causando a morte da planta ou do ramo afetado. Qualquer parte do tronco, inclusive o coleto e os ramos podem ser atacados. Quando o cancro ocorre acima do coleto, às vezes as plantas rebrotam.

O cancro-depressivo é causado pelo fungo Phomopsis sp., um patógeno secundário ou oportunista, que sobrevive em plantas mortas ou em ramos secos de gravioleiras. A doença torna-se mais forte no período da seca, que coincide com os períodos de temperaturas baixas e ventos mais fortes. O patógeno pode penetrar através de ferimentos causados por poda de ramos, estresse causado por frio, deficiências hídrica e nutricional, e ataque de pragas. No entanto, a principal porta de entrada desse fungo tem sido as aberturas naturais (axilas de ramos), principalmente as cicatrizes deixadas no tronco pelo secamento natural de ramos basais.

É uma doença de controle difícil, porque geralmente os sintomas só se tornam visíveis em estágios avançados da doença, fase em que o controle não é mais possível. Desta forma, as seguintes medidas de controle preventivo devem ser aplicadas: podar todos os ramos da base das plantas, quando estas atingirem $1 \mathrm{~m}$ de altura, e imediatamente pincelar a pasta recomendada para o controle da broca-do-tronco; manter as plantas adubadas adequadamente e evitar estresses hídricos;no início das chuvas, recomenda- 
-se pulverizar ou pincelar o tronco/caule e axilas dos ramos com sinais (manchas pretas), a cada 15 ou 20 dias, com fungicidas à base de cobre ou tiofanato metílico; podar e destruir todos os galhos secos existentes no pomar; se a doença já estiver estabelecida, recomenda-se raspar superficialmente toda a parte lesionada (escura) e, posteriormente, pincelar o local com pasta à base de cobre ou tiofanato metílico.

\section{- Podridão-parda dos frutos da gravioleira (Rhizopus stolonifer)}

É uma doença de grande expressão econômica para a gravioleira. Afeta flores e frutos de qualquer idade, porém ocorre com mais frequência nas fases de colheita e pós-colheita. Foi relatada e descrita pela primeira vez no Distrito Federal, onde vem provocando prejuízos expressivos por causar a queda e apodrecer frutos em campo e na pós-colheita (JUNQUEIRA et al., 2003). Segundo Nieto-Angel et al. (1998), no Estado da Bahia, essa doença vem provocando perdas de 50 a $70 \%$ de frutos na pós-colheita.

Os sintomas iniciam-se a partir do pedúnculo, local de penetração do fungo, ou a partir de perfurações causadas por brocas. Quando a penetração ocorre naturalmente através do pedúnculo, a doença atinge primeiramente a parte central do fruto, causando a podridão-parda da polpa. Posteriormente, ao atingir a casca, esta adquire uma coloração pardo-escura. Em períodos de alta umidade, o fungo desenvolve-se sob a epiderme da casca atacada, formando crostas descontínuas e esbranquiçadas que são o seu micélio. Quando o fruto atacado é aberto ou ferido, observa-se, após 24 horas, o crescimento de estruturas similares a pelos de coloração cinza, que são frutificações do patógeno. Posteriormente, o fruto pode desintegrar-se ou mumificar totalmente. Quando a penetração do fungo ocorre por perfurações de brocas, as lesões de coloração pardo-escura progridem do ferimento para as demais partes do fruto.

A doença é causada pelo fungo Rhizopus stolonifer Sac. que sobrevive de um ano para o outro em frutos secos, caídos ou remanescentes. Além da graviola, esse fungo ataca também flores e frutos de jaqueira. A disseminação do patógeno pode ser feita pelo vento, pela chuva, pela ação do homem e de insetos, principalmente a broca-da-semente $(B e-$ phrateloides muculicollis). A doença pode ocorrer em qualquer estação do ano, mas é mais frequente durante o período chuvoso.

Em relação ao controle, fungicidas tiofanato metílico, chlorothalonil + tiofanato metílico e mancozeb não foram eficazes no controle dessa doença em flores e frutos de gravioleira (JUNQUEIRA et al., 2003). Dessa forma, como medidas preventivas, recomendam-se controlar adequadamente as brocas da semente e do fruto, e evitar a permanência no pomar de frutos doentes, secos e mumificados, que servem como fonte de inóculo primário da doença.

\section{- Podridão-preta-do-fruto da gravioleira} (Phytophthora sp.)

No Brasil, esta doença foi constatada pela primeira vez em 1991, em gravioleiras cultivadas no Distrito Federal (JUNQUEIRA et al., 2003; GRAMACHO et al., 2001). Na Colômbia, Costa Rica e Venezuela, essa doença já assume importância econômica. No Brasil, essa doença assume importância secundária pelo fato de os pomares de gravioleiras encontrarem-se, em sua maioria, implantados nas regiões Norte e Nordeste do País, onde as condições climáticas são desfavoráveis à ocorrência desta doença. Os sintomas são caracterizados, inicialmente, pelo aparecimento de manchas marrom-escuras na casca do fruto, que progridem em todos os sentidos. Com o tempo, a casca escurece e apodrece totalmente,tornando o fruto imprestável. Posteriormente, sobre toda a superfície do fruto, ocorre um crescimento micelial branco, que são as frutificações e micélios do patógeno. A doença ataca com maior frequência os frutos em fase de pré-maturação.

$\mathrm{O}$ agente causador da doença é o fungo Phytophthora sp., que pode atacar frutos de qualquer idade, em regiões onde ocorrem, durante a frutificação, períodos chuvosos prolongados, aliados a temperaturas entre 18 e $22^{\circ} \mathrm{C}$. Como medida de controle preventivo, recomenda-se a eliminação de frutos doentes do pomar.

\section{- Outras doenças da pinheira, atemoleira e cherimoleira \\ -Doenças de Origem biótica}

Outras doenças de menor expressão econômica para pinheira foram descritas e ilustradas por Junqueira et al. (2003), como:

- Pinta-preta (Coniothyrium sp.): Essa doença vem provocando intenso desfolhamento em ateiras cultivadas na região geoeconômica de Paracatu-MG. Segundo Junqueira et al. (2003), os principais sintomas observados nas folhas são lesões necróticas, escuras, circulares, medindo até dois centímetros de diâmetro. Sobre essas lesões, podem ser observadas várias pontuações escuras com menos de $0,3 \mathrm{~mm}$ que são os ascostromas ou estruturas de frutificação do fungo. Em uma mesma folha, podem ocorrer várias lesões que, geralmente, coalescem e provocam a queda das folhas. A doença é causada por um fungo que tem como seu anamorfo o fungo Coniothyrium 
sp. O controle dessa doença vem sendo feito de forma satisfatória, com pulverizações de fungicidas usados para o controle da antracnose e de outras doenças da parte aérea da pinheira.

- Rubelose (Corticium sp.): De acordo com Junqueira et al. (2003), os sintomas iniciais são caracterizados pela redução do tamanho das folhas mais novas, pela perda da coloração original da folhagem que adquire um verde-pálido. Com o tempo, as folhas murcham, secam e permanecem presas ao galho por um tempo. Posteriormente, o galho seca. No local da infecção ou de penetração do patógeno, que pode ser no tronco ou em ramos, observa-se inicialmente uma área lesada, com pequenas rachaduras na casca e exsudação de goma. Essas lesões progridem rapidamente tanto no sentido do ápice como para a base do tronco ou do ramo. As rachaduras aumentam de tamanho, a casca se rompe e a epiderme se ergue. Sob as partes erguidas, surge uma massa micelial de cor laranja-clara ocupando toda a superfície lesada. Mais tarde, esse micélio, ainda sob o súber, ocupa toda a extensão dos galhos mais grossos e do tronco. Posteriormente, surge grande quantidade de cistídios com até $2 \mathrm{~mm}$ de comprimento por $1 \mathrm{~mm}$ na base, mas basídios não foram vistos. Como medida de controle, recomendam-se podas periódicas para manter a copa mais aberta e mais ventilada. Caso a doença já esteja estabelecida, recomenda-se a poda dos galhos afetados.

- Queima-do-fio (Pellicularia koleroga): É uma doença que ataca principalmente a folhagem de plantas adultas na região Amazônica. Em alguns casos, chega a causar danos expressivos, sendo necessária a aplicação de fungicidas. Além de anonáceas cultivadas, como gravioleira, atemoleira e pinheira, este fungo ataca também outras plantas cultivadas e nativas. É uma doença de importância secundária, exceto na Amazônia Úmida, em certas épocas do ano.

- Tombamento das mudas ou damping-off (Rhizoctonia solani, Fusarium spp. Pythium sp.)

É uma doença que se restringe às condições de sementeira, tanto no período pré como em pós-emergência. Sua ocorrência deve-se a situações de alta umidade, alto teor de matéria orgânica, sombreamento excessivo e semeadura densa, associados à presença dos patógenos.

- Mancha de Cylindrocladium quinqueseptatum: Os principais sintomas são manchas foliares escuras de contorno celular. Com o passar do tempo, a doença pode causar desfolhamento total da planta. Para o controle, recomenda-se o mesmo tratamento indicado para a antracnose.
- Mancha-amarela das folhas: O agente causal é um Rhabdovirus da família Rhabdoviridae. Segundo Freire e Cardoso (1997), os sintomas dessa virose são caracterizados pela presença de manchas amareladas, difusas, sem contornos definidos, dispersas sobre o limbo foliar, quase sempre causando sua distorção. É comum o clareamento das nervuras. Plantas adultas infectadas exibem nítido declínio, com folhas menores e progressivas, com diminuição da produtividade. Essa doença também pode afetar a gravioleira.

- Manchas-de-alga (Cephaleurus mycoidea): Os sintomas são caracterizados por manchas circulares, de cor alaranjada a ferrugínea, com 2 a 10 mm de diâmetro.

- Cercosporiose (Cercospora annonae) A cercosporiose afeta apenas folhas, raramente assumindo alguma importância econômica, quando infecções mais severas podem determinar alguma desfolha. Além da gravioleira, o patógeno pode infectar a ateira, á cherimoleira, a condessa e outras espécies do gênero Annona. Pulverizações com os fungicidas indicados para a antracnose são eficazes no controle dessa doença.

- Ferrugens : No Estado de São Paulo, já foram encontradas folhas de cherimólia atacadas de forma severa por Phakopsora neocherimoliae, representando a primeira ocorrência desse fungo no Brasil (FERRARI et al., 2004). Em 2011, Freire et al. constataram infecção severa de Batistopsora crucis-filii em plantios comerciais de pinha e de atemoia, na Chapada do Apodi, Ceará, e nos demais estados do Nordeste.

- Verrugose (Elsinoe annonae Bitan. \& Jenk.): Essa doença vem sendo observada com frequência em cherimólia no Distrito Federal. De acordo com Agustín e Alviter (1996), ela ocorre na América Central, Brasil e Venezuela. Os sintomas dessa doença são caracterizados pela formação de um tecido corticoso de coloração marrom-clara sobre a casca dos frutos, podendo ocupar mais de $50 \%$ da superfície do fruto, às vezes com rachaduras profundas (JUNQUEIRA et al., 2003). Os sintomas podem ser confundidos com aqueles causados por tripes e vaquinhas que raspam a casca.

-Nematoides: A espécie Radopholus similis foi encontrada no Estado do Ceará, causando a morte de plantas adultas de fruteira-do-conde (PONTE, 1984, citado por FREIRE ; CARDOSO, 1997). O nematoide cavernícola, o Radopholus similis, é um endoparasita obrigatório, que provoca lesões profundas nas raízes de fruteira-do-conde. De acordo com Freire et al. (2011), o nematoide Pratylenchus coffeae está associado ao escurecimento e à necroses 
de raízes de pinheira no Ceará. Estes autores listam outros nematoides associados a raízes de anonáceas. fisiológicos)

- Doenças de origem abiótica (distúrbios

- Rachaduras dos frutos: Corresponde a um distúrbio fisiológico e está relacionado com a ocorrência de chuvas durante a formação e o desenvolvimento dos frutos, após um veranico.

- Deformação do fruto: A principal característica desse distúrbio é a má-formação dos frutos, que reduz seu valor de mercado. Sendo um fruto composto e dependente de agentes polinizadores, o fruto de anonáceas, em geral, só se torna perfeito quando todos os óvulos que derem origem aos frutilhos forem fertilizados eficientemente. Desta forma, caso um ou mais deles não forem fecundados, ocorre a deformação do fruto.

- Outras doenças da gravioleira

- Mancha-zonada (Sclerotium coffeicolum): É uma doença comum na região Norte e não causa danos expressivos

- Mancha-das-folhas (Scolecotrichum sp. ou Phoma sp.): Provoca manchas nas folhas que, posteriormente, transformam-se em lesões escuras e necróticas. Por se tratar de doenças de importância secundária, não se recomendam medidas de controle.

- Mela ou murcha (Sclerotium rolfsii): Afeta mudas de gravioleiras. Por ser transmitida por solo contaminado, recomenda-se, como controle preventivo, não utilizar solos de áreas que estejam ou foram, nos últimos 4 anos, cultivados com amendoim, girassol, feijão. Os sintomas da doença são caracterizados pela murcha seguida de morte da planta. Posteriormente, na região do coleto, surge um crescimento micelial branco, que forma um grande número de estruturas esféricas brancas ou amareladas, medindo aproximadamente $1 \mathrm{~mm}$ de diâmetro, que são os esclerócios.

\section{REFERÊNCIAS}

AGUSTIN, J. A.; ALVITER, A.R.. El cultivo de la chirimoya (Annona cherimola Mill.) en el estado de Michoacán. Carretera México: Universidad Autonoma Chapingo, 1996. p. 39-47.

BONAVENTURE, L. El cultivo de la chirimoya y de su híbrido atemoya en Brasil. Acta Horticulturae, Wageningen, n.497, p.147-151, 1999.
FERRARI, J. T.; NOGUEIRA, E.M.C.; HENNEN, J. F.; FIGUEIREDO, M. B.; COUTINHO, L.N.; LOUZEIRO, I. M. Ocorrência e controle da ferrugem em cherimólia no Estado de São Paulo. Arquivos do Instituto Biológico, São Paulo, v. 71, n.1, p. 95-98, 2004.

FREIRE, F. das C. O.; CARDOSO, J. E. Doenças das anonáceas. In: SÃO JOSÉ, A.R. Anonáceas: produção e mercado (pinha, graviola, atemóia e cherimólia). Vitória da conquista: UESB, 1997. p.196-213.

FREIRE, F. das C. O.; MARTINS, M. V. V.; CARDOSO, J. E. Doenças emergentes da ata ou pinha (Annona Squamosa L.) no Estado do Ceará. Fortaleza: Embrapa Agroindústria de Alimentos, 2011. 169 p. (Comunicado Técnico, 169)

GRAMACHO, K.P.; BEZERRA, J. L.; JUNQUEIRA, N.T.V. Phytophthora sp. em espécies da família Anonacea. In: LUZ, E.D.M.N.; SANTOS, A. F. DOS; MATSUOKA, K.; BEZERRA, J. L. (Ed.). Doenças causadas por Phytophthora no Brasil. Campinas, Livraria Rural, 2001. p.91-99.

JUNQUEIRA, N. T. V. ; CUNHA, M. M. ; JUNQUEIRA, K. P. . Doenças e Pragas de anonáceas. In: MANICA, I. ET AL. Frutas anonáceas: ata ou pinha, atemólia, cherimólia e graviola: tecnologia de produção, pós-colheita e mercado. Porto Alegre: Cinco Continentes Editora, 2003. v.1, p.387-440.

JUNQUEIRA, N.T.V.; CUNHA, M.M.da.; OLIVEIRA, M.A.S.; PINTO, A.C.de Q. Graviola para exportação: aspectos fitossanitários. Brasília: Embrapa, SPI, 1996. 67p. (Série publicações técnicas FRUPEX, 22).

KAVATI, R. O cultivo da Atemóia. In: DONADIO, L.C. Fruticultura tropical. Jaboticabal: FUNEP, 1992. p.69-70.

MORALES, C.F.; MANICA, I. Moléstias e pragas. In: Fruticultura: Cultivo das anonáceas: Ata, Cherimólia, Graviola. Porto Alegre: EVANGRAF, 1994. p.78-91.

NIETO-ANGEL, D.; SÃO JOSÉ, A.; SOUZA, S. E. Perdas na pré e pós-colheita de graviola no Estado da Bahia. In: CONGRESSO BRASILEIRO DE FRUTICULTURA, 15., 1998, Poços de Caldas. Anais.... Poços de Caldas: SBF, 1998. p. 400. 
RIBEIRO, I. J. A. Principais doenças de algumas frutíferas tropicais. In: DONADIO, L.C. Fruticultura tropical. Jaboticabal: FUNEP, 1992. p. 247-268.

TAKANAKI, L.M. Identificação de Colletotrichum gloeosporioides de Atemoia (Annona cherimola $x$ Annona squamosa) por meio de caracterização patogénica, cultural e morfológica. 2008. $46 \mathrm{f}$. Dissertação (Mestrado) - Universidade Estadual Paulista, Faculdade de Ciencias Agronômicas, Botucatu, 2008.
TOKUNAGA, T. A cultura da atemóia. Campinas: CATI, 2000. 80p. (Boletim Técnico, 233). 